International Journal of Social Sciences and Humanities
Available online at http://sciencescholar.us/journal/index.php/ijssh
Vol. 3 No. 1, April 2019, pages: 102 114
e-ISSN: 2550-7001, p-ISSN: 2550-701X
https://doi.org/10.29332/ijssh.v3n1.268

\title{
Millennial Generation in Accepting Mutations: Impact on Work Stress and Employee Performance
}

\section{Putu Irma Yunita ${ }^{a}$, I Gusti Ngurah Widya Hadi Saputra ${ }^{\mathrm{b}}$}

Article history: Received 27 August 2018, Accepted: 31 December 2018, Published: 1 April 2019

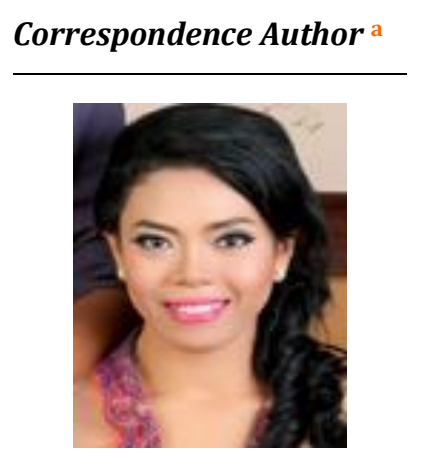

Keywords

employee performance;

job transfer;

millennial generation;

mutation;

stress;

\begin{abstract}
This study is aimed at examining the impact of work mutations on work stress, as well as on employee performance. Having seen the differences in the phenomenon that occurs between female employees and male employees. The respondents were included in this study were 108 millennial employees of Dental Clinic Centre, consisting of 68 women and 40 men. The technique of data analysis used is WrapPLS. The results of the study indicate that work mutations have a negative impact on work stress, as well as work stress negatively affects performance. Work stress furthermore mediates the impact of work mutations on employee performance. It's also found that there were differences between men and women in facing the work mutations that occurred. The employee of men is found to be calmer and not stressed in facing the work mutations that occur, while women are the opposite.
\end{abstract}

e-ISSN: 2550-7001, p-ISSN: 2550-701X ๑ Copyright 2019. The Author. SS Journals Published by Universidad Técnica de Manabí. This is an open-access article under the CC BY-SA 4.0 license (https://creativecommons.org/licenses/by-sa/4.0/) All rights reserved.

\section{Contents}

Abstract.

1. Introduction.

2. Materials and Methods .

105

3. Results and Discussions

4. Conclusion

Acknowledgements.

a Faculty of Economic \& Business, Universitas Pendidikan Nasional (Undiknas), Denpasar, Indonesia

b Faculty of Economic \& Business, Universitas Pendidikan Nasional (Undiknas), Denpasar, Indonesia 


\section{Introduction}

The change in work atmosphere is a common phenomenon that employees will always experience in their working period. It will be felt when employees experience mutations from one department to another. Employee responses to mutations vary in each generation. The millennial generation in 2018 dominates the number of workers throughout the world. The millennials were born in 1979 to 1994 (Smola \& Sutton, 2002), now this generation is very productive in the world of work. The characteristics of the millennial generation are that they have high self-esteem, are selfish, have low loyalty and have a bad work ethic (Martson, 2007; 2009). There are concerns among researchers that the characteristics of the millennial generation will have an impact on relationships between different generations of employees, while also affecting employee and organizational performance (Alsop, Nicholson, \& Miller, 2009; Alsop, 2008; McGuire \& Hutchings, 2007). Many positive things, however, are generated by the millennial generation in the workplace, for example they are more in control of information technology compared to previous generations, besides they have the ability to see threats and opportunities from different perspectives, and millennia's tend to be more quickly adapt to new environments (Howe \& Strauss, 2000; Gorman, Nelson, \& Glassman, 2004). The millennials which are individualistic does not depend on the group in a department. If there is therfeore a mutation, the people will be very easy to accept. The intensity of mutations are too high can disrupt the quality of employees in carrying out their work, including millennials. This is due to the understanding of new tasks that have not been one hundred percent that can cause the maximum completion of a job. It will not only harm employees who experience mutations but also greatly harm the company, especially service companies that deal directly with consumers. The complaints will often occur, and the most extreme are customers who will turn to other similar companies with better service (Gronholdt et al., 2000; Deng et al., 2010).

Gender greatly influences a person's perception of the changes and pressures they experience, both in the world of work and family (Ravinarayana \& Ramakrishna, 2016; Matud, 2004; Watson et al., 2011). The men tend to use focus coping problems wherein facing problems, pressures, and changes men prefer to directly solve the problems they faced while women use focus coping emotion which is used their feelings or more emotional in dealing with a problem (Hamilton \& Fagot, 1988). It is to show that men will be calmer and less stressful in dealing with problems, while women will tend to experience stress (Shirom et al., 2008; Afolabi et al., 2010). This is a challenge for management in dealing with employees who are actually dominated by millennials, especially female employees. Reviewing the characteristics of millennials is very unwilling to be tied to the company and has the low commitment, employee turnover, in this case, cannot be avoided (Allen, 1995; Hill, 2002). If working conditions are not possible, and make these millennials uncomfortable, they will not hesitate to quit their current employment and look for other jobs.

The dental clinic is a private business entity that also conducts human resource management activities in carrying out its operations. The workforce in the health company consists of dentists, nurses, and administrative staff. The nurses who work every month will be rolled in a horizontal position, meaning nurses each month will help different doctors in preparing patient data, both in analyzing the patient's disease history, and helping the doctor when giving action. Because of frequent mutations, causing various problems to arise, among others, unlike nurses who feel confused because of the large number of patient data held by one doctor and the responsibilities faced by nurses will increase, which will affect the performance of employees in the Dental Clinic. The patients who come to the Dental Clinic have different complaints and different history of the disease. This is the motivation of researchers to further examine how nurses are dominated by millennial generations in addressing mutations, and how their psychological condition in dealing with it. Will mutations affect their performance at work?

\section{Mutation and Stress}

The purpose of management mutation is to avoid saturation in work routines that are sometimes boring (Pinder \& Schroeder, 1987; Huang, 1999). The mutation has a function that is so that employees can master and explore work in other fields. It can be interpreted as shifting positions both vertically and horizontally (Noe et al., 1988). If the mutation, however, cannot be received properly by the employee. It will have an impact on the psychological employee. The work has never been done due to it is not in the field, the difficulty

Yunita, P. I., \& Saputra, I. G. N. W. H. (2019). Millennial generation in accepting mutations: Impact on work stress and employee performance. International Journal of Social Sciences and Humanities, 3(1), 102-114. https://doi.org/10.29332/ijssh.v3n1.268 
of adapting and the severity of responsibility given by the company will have an impact in the form of work stress on employees (Munton \& Forster, 1990). Not all employees can accept the occurrence of these mutations. The more frequent mutations are carried out, the more stressed the employee's level will be. Based on this, the first hypothesis in this study is as follows

H1: Mutations have a positive effect on stress.

\section{Stress and work performance}

Job stress is a condition in which a person experiences tension due to conditions that affect him (Ganster \& Schaubroeck, 1991). Stress in the workplace is something almost every day is experienced by employees. Competition and professionalism are increasingly high which raise the many pressures that must be faced by individuals (AbuAlRub, 2004; Frese \& Fay, 2001). Employees who are always demanded with deadlines, completion of tasks, excessive workload, conflicts between employees and many other challenges. It can make stress become a factor that can hardly be avoided. It will, therefore, affect the performance of employees in a company. Research conducted Park (2007), shows that the source of work stress can come from all things, and have a different impact on everyone. His research however excessive levels of stress can cause employees to feel depressed and not concentrate on doing the work. The performance thus will decrease. Based on this, the hypothesis is arranged as follows

H2: Job stress has a negative effect on employee performance

Stassen (2004), examined the comparison of managers who were transferred to those who were not transferred. The results show that managers who experience mutations feel more stressed and experience stress with their new duties and responsibilities than those who are not transferred comfortably. This is due to the need for adjustments to the job desk and coworkers.

Lack of employee ability to adapt will have an impact on stress on him. The symptoms are various, ranging from dizziness, anxiety, insomnia, and the most extreme is depression. Stress can also affect the performance of one's employees. The more stressful the more difficult it is for someone to show their best performance. It impacts performance degradation. The following hypothesis is arranged.

H3: Job stress mediates the negative influence of mutations on employee performance

\section{Gender}

Gender is the difference in roles, functions, status, and responsibilities of men and women as a result of the socio-cultural construction that is embedded through the process of socialization from one generation to the next (Rosenthal et al., 1996). The gender, in addition, is also defined as the result of an agreement between humans that is not natural (Bem, 1993). Women are known as gentle, beautiful, emotional and motherly. While men are considered strong, rational, manly and mighty. The characteristics of these traits are interchangeable traits, for example, there are men who are meek, there are women who are strong, rational and powerful. The changes in the characteristics of these traits can occur from time to time and from place to place.

The gender greatly related to mutations influences perceptions of pressure, as well as reactions caused by mutations. Research conducted by Gyllensten \& Palmer (2015) and Gianakos (2000), shows women experience higher stress levels than men. Women who have many roles, careers in their jobs, and often experience discrimination and mutation, have a higher influence on work stress because the workload they have also tended to be higher. The men unlike wherein tend to be able to deal with stress and are ready to face the pressure that exists. The hypothesis is arranged as follows.

H4: Mutations have a positive effect on work stress in women.

H5: Mutations negatively affect work stress in men.

Regarding performance, gender can also affect a person's performance due to perceptions of working conditions experienced, in this case, mutations. Rosenthal et al., (1996) and Erickson (2005), shows that more female employees cannot show good performance because of the way they deal with stress which is considered unstable. This is inversely proportional to men where men are more able to deal with their stress so that their performance is better. For this reason, the following hypotheses can be arranged. 
H6: Job stress mediates the negative influence of mutations on employee performance in women. H7: Job stress mediates the positive effect of mutations on employee performance in men

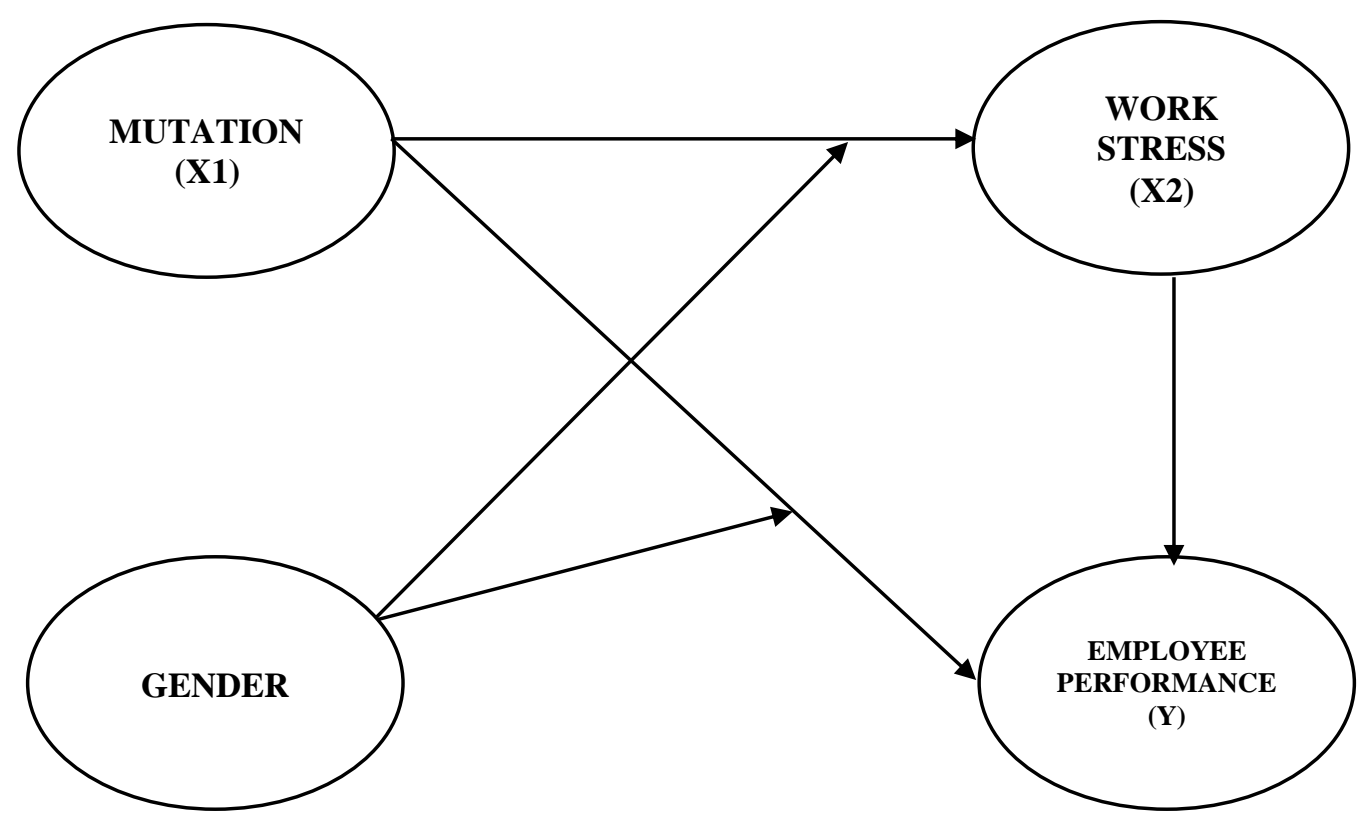

Figure 1. Framework millennial generation in accepting mutations and its impact on employee stress and employee performance

\section{Materials and Methods}

The data displayed in this study are data that show the relationship between work mutations, work stress and employee performance in the millennial generation. Another thing to be examined is the role of gender in the phenomenon that occurs. Data were obtained through the distribution of questionnaires from November 2018 to February 2019. The respondents were employees who worked at the Denpasar Dental Clinic. The sampling method used was purposive sampling with contracts, employees born between 1979 and 1994, employees had worked for at least two years, had mutations more than once in one year. To obtain data, researchers collaborated with Human Resource Management at each existing dental clinic. Based on the initial data filtering in accordance with the established criteria, 150 employees were eligible. Next, the researchers gave questionnaires to employees who had fulfilled these requirements directly. This is conducted to avoid the existence of statement items in the questionnaire that are not understood, and ensure that each statement is truly answered. Being 150 questionnaires, 108 questionnaires were returned and could be analyzed further. The response rate thus in this study was $72 \%$. Data were analyzed using SPSS version 23 for Windows, and WrapPLS software

\section{Measurement}

Dependent variables; employee performance is measured using indicators developed by Robbins (2006), which number 6 indicators, namely quality, quantity, timeliness, effectiveness, independence, and work commitment. The six indicators are measured by a Likert scale $(1$ for statement strongly disagrees, up to 5 for statements strongly agree).

Yunita, P. I., \& Saputra, I. G. N. W. H. (2019). Millennial generation in accepting mutations: Impact on work stress and employee performance. International Journal of Social Sciences and Humanities, 3(1), 102-114. https://doi.org/10.29332/ijssh.v3n1.268 
Independent variables; employee mutations are measured by 3 indicators developed by Ambarita (2015). The indicators of work mutations in this study are mutation frequency, the reason for mutation, and accuracy in making mutations. Mutation indicators are measured using a Likert scale.

Intervening variable; intervening variables in this study are job stress and are measured using 6 indicators modified by Hasibuan (2014). The six indicators are workload, leader attitude, conflict communication work time, and work authority. This indicator measurement uses a Likert scale. Moderating variable; gender is a discrete variable and its measurement is coded one for men and zero for women

\section{Result}

Based on the results of processed data using SPSS, which tests the validity and reliability of the research instrument results obtained that all indicators are declared valid and reliable. Having seen the value of the correlation coefficient of each item which is $>0.3$ and the value of Cronbach Alpha $>0.6$. It is next testing used the WrapPLS application. The purpose of using this application is the research model uses intervening and moderating variables. The software so that is more effective and efficient.

This model fit test has 3 test indices, namely Average Path Coefficient (APC), average R-squared (ARS), and Average Variances Factor (AVIF) with APC and ARS criteria accepted on condition p-value $<0.01$ or p-value $<0.05$ and AVIF is smaller than 5. The following is the output of the fit indices model from the WrapPLS 6.0 program:

Table 1

Model fit male and female indices

\begin{tabular}{ccc}
\hline Goodness of Fit & Indeks & Signifikansi \\
\hline APC & 0,305 & $p$-value $<0,001$ \\
ARS & 0,165 & $p$-value $=0,019$ \\
AVIF & 1,161 & $<5$ \\
\hline
\end{tabular}

Source: Output of WrapPLS 6.0 (2019)

The output results in Table 1 explain that APC has an index of 0.305 with a p-value $<0.001$. While ARS has an index of 0.165 with $\mathrm{p}$-value $=0.019$. The second P-value of the index shows results below $<0.05$ which means it meets the criteria and can be said to be significant. AVIF shows an index below 5 which is equal to 1.161 . The conclusion is the FIT model.

Table 2

Model fit male indices

\begin{tabular}{ccc}
\hline Goodness of Fit & Indeks & Signifikansi \\
\hline APC & 0,352 & $p$-value $=0,003$ \\
ARS & 0,207 & $p$-value $=0,040$ \\
AVIF & 1,029 & $<5$ \\
\hline
\end{tabular}

Source: Output of WrapPLS 6.0 (2019)

The output results in Table 2 explain that APC has an index of 0.352 with a p-value $=0.003$. ARS has an index of 0.207 with $p$-value $=0.040 p$ - the second value of the index shows results below $<0.05$ which means it meets the criteria and can be said to be significant. AVIF shows an index below 5 which is equal to 1.029 . The conclusion is that the model is FIT

Table 3

Model fit indices female

\begin{tabular}{ccc}
\hline Goodness of Fit & Indeks & Signifikansi \\
\hline APC & 0,247 & $p$-value $=0,008$ \\
\hline
\end{tabular}




\begin{tabular}{ccc} 
ARS & 0,126 & $p$-value $=0,071$ \\
AVIF & 1,008 & $<5$ \\
\hline
\end{tabular}

Source: Output of WrapPLS 6.0 (2019)

The output results in Table 3 explain that APC has an index of 0.247 with a p-value $=0.008$. While ARS has an index of 0.126 with $\mathrm{p}$-value $=0.071 \mathrm{p}-$ the second value of the index shows results below $<0.05$ which means it meets the criteria and can be said to be significant. AVIF shows an index below 5 which is equal to 1.029. The conclusion is the FIT model.

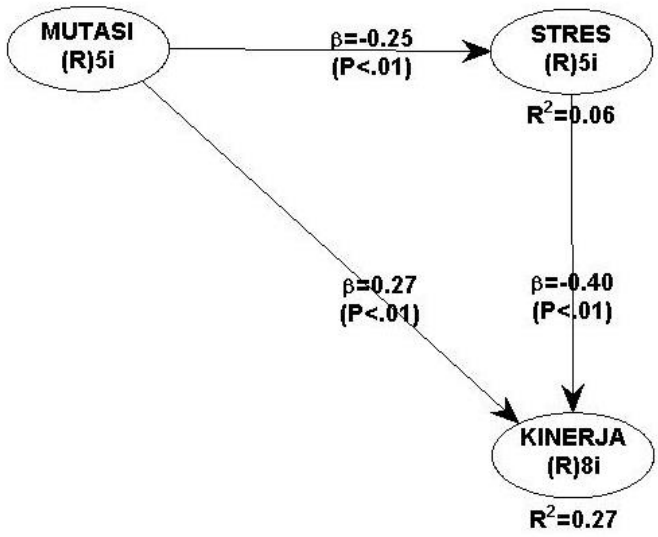

Source: Output of WrapPLS 6.0 (2019)

Figure 2. Research Models and Results of Men and Women

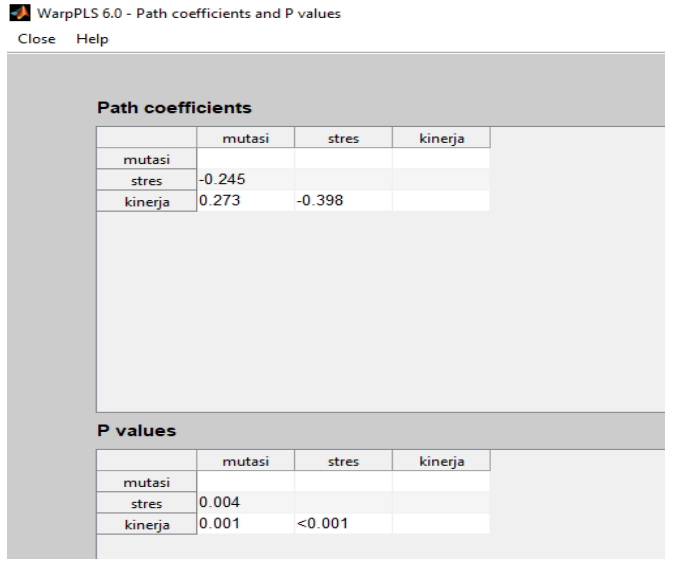

Source: Output of WrapPLS 6.0 (2019)

Figure 3. Path Coefficient P Value for Men and women

Interpretation term; Mutasi (Mutation); Stres (Stress) and Kinerja (Performance). Based on Figure 2, it can be seen the hypothesis testing in this study as follows

H1: Mutations have a positive and significant effect on employment

The test results show that the direct effect coefficient on the performance of stressed employees has a value of $\beta=-0.25$ with $p$-value $<0.01$ which means significant. But the sign in $\beta$ is negative does not match the initial hypothesis, it was in this study rejected.

H2: Stress has a negative effect on employee performance

The test results show that the direct effect stress coefficient on employee performance has the value of $\beta=$ - 0.40 with $\mathrm{p}$-value $<0.01$ which means significant. $\mathrm{H} 2$ is then accepted

H3: Mutations negatively affect employee performance through work stress as a mediating variable

Figure 3 shows that stress affects employee performance with the p-value obtained $0.001<0.05$ and the Coefficients path value of -0.398 . This means that stress can be a mediator of the relationship between mutations with employee performance. H3 is then acceptable.

Yunita, P. I., \& Saputra, I. G. N. W. H. (2019). Millennial generation in accepting mutations: Impact on work stress and employee performance. International Journal of Social Sciences and Humanities, 3(1), 102-114. https://doi.org/10.29332/ijssh.v3n1.268 


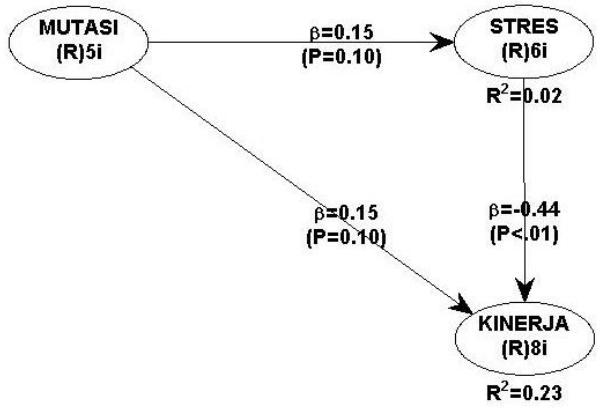

Source: Output of WrapPLS 6.0 (2019)

Figure 4. Research Model and Women's Results

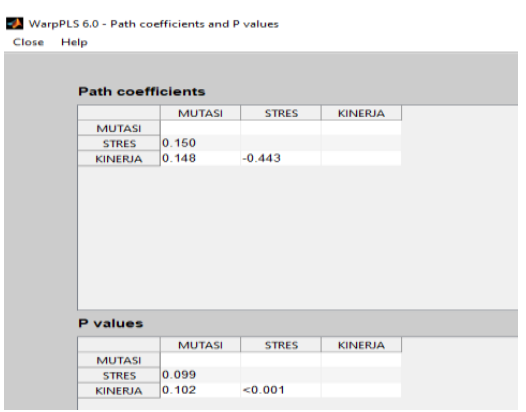

Source: Output of WrapPLS 6.0 (2019)

Figure 5. Women's Path Coefficient P Value

Interpretation term; Mutasi (Mutation); Stres (Stress) and Kinerja (Performance). Based on figure 4, it can be seen the hypothesis testing in this study as follows:

H4: Mutations have a positive effect on work stress in women

The test results show that the direct effect mutation coefficient on stress has a value of $\beta=0.15$ with $p$ value $=0.10$ which means it is not significant, it was in this study rejected.

H6: Mutations negatively affect employee performance through work stress on women

Figure 5 shows that stress affects employee performance with the $p$-value obtained $0.001<0.05$ and the path Coefficients value of -0.444 . This means that stress can be a mediator of the relationship between mutations with employee performance. H6 then is acceptable.

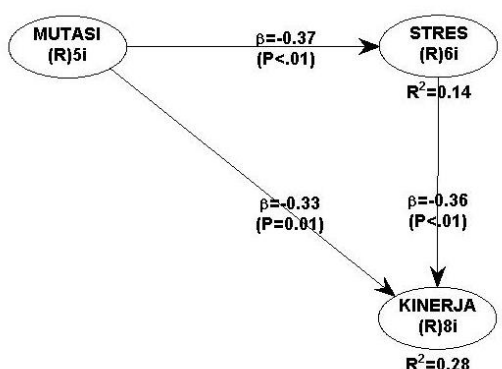

Source: Output of WrapPLS 6.0 (2019)

Figure 6. Research Models and Results of Men

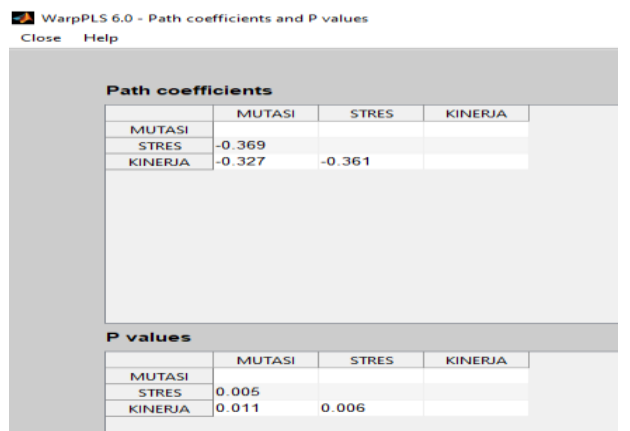

Source: Output of WrapPLS 6.0 (2019)

Figure 7. Male Path Coefficient P Value

Interpretation term; Mutasi (Mutation); Stres (Stress) and Kinerja (Performance). Based on Figure 6, it can be seen the hypothesis testing in this study as follows:

H5: Mutations negatively affect work stress in men

The test results show that the direct effect mutation coefficient on the performance of stressed employees has a value of $\beta=-0.37$ with $p$-value $<0.01$ which means significant. H5 is then accepted

H7: Mutations have a positive effect on employee performance through stress on men

Figure 7 shows that stress affects employee performance with the p-value obtained $0.006<0.05$ and the path Coefficient value of -0.331 . This means that stress can be a mediator of the relationship between mutations with employee performance. H7, however, can be rejected due to the value of path coefficients shows negative. 


\section{Results and Discussions}

The Millennials with characteristics that are independent and adaptable to the environment, both the work environment and the social environment are not affected by changes that in this case are mutations. They are even though transferred to a new workplace with a new working atmosphere and new people. It does not affect the psychological condition of the millennials. They, therefore, do not experience work stress. The millennial generation in this study gave a positive response to the mutations occur. In accordance with the previous research, these people are people who are easily bored with monotonous working conditions and always want new things in their lives (Herriot, 2002; Ondeck, 2002). The one hypothesis which says mutations has a positive effect on work stress is not answered. The results of testing the data show the opposite results where mutations have a negative effect on work stress. The more frequent the mutation the lower the stress level. The results of this study are in accordance with research Ellyzar et al., (2017), found that mutations have a good impact such as increasing work experience for employees. The employees thus can eliminate stress in their work and can reduce boredom.

Regardless of the millennial generation, someone who experiences work stress, with high levels of stress will greatly affect a person's psychological and physical condition. Work passion will decrease because mental fatigue is experienced due to stress. Employees who are always demanded with deadlines, completion of tasks, excessive workload, conflicts between employees and many other challenges that can make stress become a factor that can hardly be avoided. It will, therefore, affect the decline in employee performance. Related to hypothesis two which states that stress has a negative effect on employee performance, in this study, the hypothesis is supported. These results are in accordance with the research Myers \& Sadaghiani (2010) and Chou (2012), showing that millennials who are in an organization, still feel stress when the work target is not achieved. It will result in a decrease in performance in the future. In a non-conducive environment, such as high conflict with coworkers, excessive workload, leaders who lack motivation can cause a person to become depressed. The pressure left to accumulate will eventually become an atomic bomb. It can damage the mental and physical health of employees. The impact will be detrimental to the company because employees who experience stress result in a decrease in performance

The third hypothesis is to detect work stress variables as mediating variables on the effect of motivation on performance. Mutations made by the company to employees in a short time are not always acceptable to all employees. Employees who cannot adapt to the new environment greatly affect the performance of their employees. The higher or often the mutation is carried out the lower the performance of its employees. If the person experiences stress due to mutations that are too often it greatly affects the performance of his employees. It was answered significantly and in accordance with Main research (2017) and Gilboa et al., (2008), found that mutations had an effect on employee performance and had a negative impact through stress. Another reason that can be explained in this study is the percentage of respondents who are dominated by women, where based on strategy coping theory. The women will be more easily stressed facing stressful situations. Due to the women use emotions more than logic in dealing with problems. It will impact on its performance in the company

The fourth hypothesis is mutations have a positive effect on job stress in women at Dental Clinic Center Denpasar. But the results of the analysis showed that mutations had no significant effect on stress in women as indicated by $\mathrm{p}=0.10$. Hofstede et al., (2010), states that in a collectivist culture, work is a supporter of family continuity. Work is a strong indicator of one's financial side. The stronger one's financial quality and happier life. This causes even though employees experience stress due to mutations or other factors, but these employees still need work to meet their financial needs and still try to work optimally for their company. In a study conducted by Gyllensten \& Palmer (2015), it was shown that women experience higher stress levels than men. The women who have many roles experience greater discrimination and mutations often compared to men so that they have a higher level of work stress. Unlike men, they tend to be able to deal with stress and are ready to face the pressure that exists, even though it is as heavy as the work at hand

Frequent mutations carried out cause stress levels to employees. The mutations, however, are not a major factor affecting stress levels in female employees. This means that there are other things that make women's stress levels increase. This can happen because most of the respondents in this study were women aged

Yunita, P. I., \& Saputra, I. G. N. W. H. (2019). Millennial generation in accepting mutations: Impact on work stress and employee performance. International Journal of Social Sciences and Humanities, 3(1), 102-114. https://doi.org/10.29332/ijssh.v3n1.268 
between 19 years and 28 years, where this age is a millennial generation who likes change, gets bored quickly and is active in technology development

In contrast to women, hypothesis 5 in this study that mutations have a negative effect on work stress and occur in men, can be verified. Based on strategy coping theory, men in accepting a pressure will be more able to control emotions because they tend to use logic in dealing with existing pressure. Male employees in the millennial generation feel happy when the mutation is done. They assume that mutations can eliminate the work stress they feel, especially the saturation with monotonous work, even though the work to be faced will increase but they tend to be ready to do it. The results of this study are in line with the research conducted by Wiley (2016), and Gyllensten \& Palmer (2015), who found that men tend to be able to deal with stress and are ready to face the pressure, so they are very positive to accept the changes that occur including work they

Regarding the analysis using warps version, 6.0 shows that mutations have a negative and significant effect on employee performance through stress in women at the Dental Clinic Center Denpasar. On testing the hypothesis, the test results show stress has an effect on employee performance with the p-value obtained $0.001<0.05$ and the path Coefficient value of -0.444 . It means that stress can be a mediator of the relationship between mutations with employee performance. H6 is therefore accepted because the path coefficients value is negative. The mutations have a negative and significant effect on employee performance through stress on women.

The women in facing a problem will feel higher stress than men. The female employees assume that mutations make themselves stressful because they have to add to their burdens, responsibilities, and other jobs. They also have to build communication with new people. It can make you feel awkward, uncomfortable, resulting in a decrease in performance. It thus can be concluded that the more frequent mutations are carried out the lower the performance of employees, because of perceived job stress

Unlike the nature of women, men are ready to face the pressure that exists. The male employees assume that mutations can reduce work stress. The more frequent mutations occur, the stress level of male employees will tend to decrease. If male employees experience excessive stress. It will have an impact on decreasing employee performance even though. It is considered male employees are more able to deal with stress. For this reason, Hypothesis 7 in this study was rejected.

\section{Conclusion}

The millennials have unique characteristics, due to the management careful in managing their employees. Their nature is independent, easily bored, but easy to adapt to change, a tough challenge for human resource management, in carrying out the functions of human resources. It examines the relationship between mutations with work stress and the perceived performance of millennial generation employees, shows evidence that, globally, millennial employees like company policies in terms of mutations. It is evidenced the more frequent mutations carried out the better the employee's performance, even though at the beginning of the placement. It is caused by psychological stress for employees so that employees experience mild stress. The adaptation however in the new environment will make feel uncomfortable for some people, including millennials. This uncomfortable condition can reduce employee performance. It thus can be concluded mutations cause employees to feel stressed. It will have an impact on performance degradation. If mutations however conversely make employees happy, then an increase in performance will occur.

It can also be concluded that gender greatly influences employee's perceptions of the mutation policies carried out by the company. The women will feel more stress if the mutations are carried out. This is very different from men who consider mutations to be pleasant. The difference in views between men and women has an impact on performance. The men's performance will remain stable or increase even though their work environment changes. The women's performance, on the contrary, will decrease when changes occur.

There are many shortcomings in the current study. It needs to be addressed in future studies. The details of the respondent's marital status were not explained in detail. This is important because many of the differences that can be experienced by married and unmarried employees are related to perceived stress. The pressure experienced by married employees is much higher than that of unmarried employees. This is very related to the stress they will experience. The transfer of the employee studied is still general in nature, in subsequent studies. It is better to differentiate the transfer of employees who are promotional, parallel, or 
reduce the grade of employees. It can very clear explain the feelings of employees when these conditions are experienced. Finally, to generalize the results of the study, respondents should be used in each district, not only in one district.

\section{Acknowledgments}

Our deep and sincere gratitude were presented to God for having granted us the ability and the opportunity to complete this article. We would also like to thank our friends for their support, their patience, their contribution, and their valuable input, therefore, this article could be completed. We would also to Human Resource Manager at Bali International Dental Centre and 911 Dental Clinic Implant Center who have assisted in proving information and the research data.

Yunita, P. I., \& Saputra, I. G. N. W. H. (2019). Millennial generation in accepting mutations: Impact on work stress and employee performance. International Journal of Social Sciences and Humanities, 3(1), 102-114. https://doi.org/10.29332/ijssh.v3n1.268 


\section{References}

AbuAlRub, R. F. (2004). Job stress, job performance, and social support among hospital nurses. Journal of nursing scholarship, 36(1), 73-78. https://doi.org/10.1111/j.1547-5069.2004.04016.x

Afolabi, O. A., Awosola, R. K., \& Omole, S. O. (2010). Influence of emotional intelligence and gender on job performance and job satisfaction among Nigerian policemen. Current Research Journal of Social Sciences, 2(3), 147-154.

Allen, B. J. (1995). "Diversity"; and organizational communication. https://doi.org/10.1080/00909889509365420

Alsop, R. (2008). The trophy kids grow up: How the millennial generation is shaking up the workplace. John Wiley \& Sons.

Armstrong-Stassen, M. (1993). Production workers' reactions to a plant closing: The role of transfer, stress, and support. Anxiety, Stress and Coping, 6(3), 201-214. https://doi.org/10.1080/10615809308248380

Armstrong-Stassen, M. (2004). Managers' perceptions of their work group and their own performance and well-being following a job transfer. Public Personnel Management,33(1), 47-60. https://doi.org/10.1177\%2F009102600403300104

Bem, S. L. (1993). The lenses of gender: Transforming the debate on sexual inequality. Yale University Press.

Chou, S. Y. (2012). Millennials in the workplace: A conceptual analysis of millennials' leadership and followership styles. International Journal of Human Resource Studies, 2(2).

Deng, Z., Lu, Y., Wei, K. K., \& Zhang, J. (2010). Understanding customer satisfaction and loyalty: An empirical study of mobile instant messages in China. International journal of information management, 30(4), 289300. https://doi.org/10.1016/j.ijinfomgt.2009.10.001

Ellyzar, N., \& Yunus, M. (2017). Pengaruh mutasi kerja, beban kerja, dan konflik interpersonal terhadap stress kerja serta dampaknya pada kinerja pegawai bpkp perwakilan provinsi aceh. Jurnal Magister Manajemen, 1(1), 35-45.

Erickson, R. J. (2005). Why emotion work matters: Sex, gender, and the division of household labor. Journal of marriage and family, 67(2), 337-351. https://doi.org/10.1111/j.0022-2445.2005.00120.x

Erickson, T. J., Alsop, R., Nicholson, P. A. M. E. L. A., \& Miller, J. (2009). Gen Y in the Workforce. Harvard Business Review, 87(2), 43-49.

Frese, M., \& Fay, D. (2001). 4. Personal initiative: An active performance concept for work in the 21st century. Research in organizational behavior,23, 133-187. https://doi.org/10.1016/S01913085(01)23005-6

Ganster, D. C., \& Schaubroeck, J. (1991). Work stress and employee health. Journal of management, 17(2), 235271. https://doi.org/10.1177\%2F014920639101700202

Gianakos, I. (2000). Gender roles and coping with work stress. Sex roles, 42(11-12), 1059-1079. https://doi.org/10.1023/A:1007092718727

Gilboa, S., Shirom, A., Fried, Y., \& Cooper, C. (2008). A meta-analysis of work demand stressors and job performance: examining main and moderating effects. Personnel Psychology,61(2), 227-271. https://doi.org/10.1111/j.1744-6570.2008.00113.x

Gorman, P., Nelson, T., \& Glassman, A. (2004). The Millennial generation: A strategic opportunity. Organizational Analysis (15517470), 12(3).

Gronholdt, L., Martensen, A., \& Kristensen, K. (2000). The relationship between customer satisfaction and loyalty: cross-industry differences. Total quality management, 11(4-6), 509-514. https://doi.org/10.1080/09544120050007823

Gyllensten, K., \& Palmer, S. (2005). The role of gender in workplace stress: A critical literature review. Health education journal, 64(3), 271-288. https://doi.org/10.1177\%2F001789690506400307

Hamilton, S., \& Fagot, B. I. (1988). Chronic stress and coping styles: A comparison of male and female undergraduates. Journal of personality and social psychology, 55(5), 819. https://psycnet.apa.org/doi/10.1037/0022-3514.55.5.819

Hill, R. P. (2002). Managing across generations in the 21st century: Important lessons from the ivory trenches. Journal of Management Inquiry, 11(1), 60-66. https://doi.org/10.1177\%2F1056492602111020

Hoftede, G., Hofstede, G. J., \& Minkov, M. (2010). Cultures and organizations: software of the mind: intercultural cooperation and its importance for survival. McGraw-Hill.

Howe, N., \& Strauss, W. (2000). Millennials rising: The next great generation. Vintage. 
Huang, H. J. (1999). Job rotation from the employees' point of view. Research and Practice in Human Resource Management, 7(1), 75-85.

KS, R. (2016). Impact of job stress on employee's performance: an empirical study. Journal on Management, 11(1).

Marston, C. (2009). Myths about Millennials: Understand the myths to retain Millennials. Retrieved June, 23(2009), 113-123.

Marston, C. (2010). Motivating the" What's in it for me?" workforce: Manage across the generational divide and increase profits. John Wiley \& Sons.

Matud, M. P. (2004). Gender differences in stress and coping styles. Personality and individual differences, 37(7), 1401-1415. https://doi.org/10.1016/j.paid.2004.01.010

McGuire, D., Todnem By, R., \& Hutchings, K. (2007). Towards a model of human resource solutions for achieving intergenerational interaction in organisations. Journal of European industrial training, 31(8), 592-608. https://doi.org/10.1108/03090590710833651

Munton, A. G., \& Forster, N. (1990). Job relocation: Stress and the role of the family. Work \& Stress, 4(1), 75-81. https://doi.org/10.1080/02678379008256967

Myers, K. K., \& Sadaghiani, K. (2010). Millennials in the workplace: A communication perspective on millennials' organizational relationships and performance. Journal of Business and Psychology, 25(2), 225238. https://doi.org/10.1007/s10869-010-9172-7

Noe, R. A., Steffy, B. D., \& Barber, A. E. (1988). An investigation of the factors influencing employees'willingness to accept mobility opportunities. Personnel Psychology, 41(3), 559-580. https://doi.org/10.1111/j.17446570.1988.tb00644.x

Ondeck, D. M. (2002). Intergenerational issues in the workplace. Home Health Care Management \& Practice, 14(5), 391-392. https://doi.org/10.1177\%2F1084822302014005013

Park, J. (2007). Work stress and job performance. Ottawa, Canada: Statistics Canada.

Pinder, C. C., \& Schroeder, K. G. (1987). Time to proficiency following job transfers. Academy of Management Journal, 30(2), 336-353. https://doi.org/10.5465/256278

Rosenthal, P., Guest, D., \& Peccei, R. (1996). Gender differences in managers' causal explanations for their work performance: a study in two organizations. Journal of occupational and organizational psychology, 69(2), 145-151. https://doi.org/10.1111/j.2044-8325.1996.tb00606.x

Shirom, A., Shechter Gilboa, S., Fried, Y., \& Cooper, C. L. (2008). Gender, age and tenure as moderators of workrelated stressors' relationships with job performance: A meta-analysis. Human Relations, 61(10), 13711398. https://doi.org/10.1177\%2F0018726708095708

Utama, H. Y. (2017). Hubungan antara coping strategi dengan stres kerja disebabkan oleh mutasi pada pegawai negeri sipil (pns) di kabupaten merangin (Doctoral dissertation, Universitas Mercu Buana Yogyakarta).

Watson, S. B., Goh, Y. W., \& Sawang, S. (2011). Gender influences on the work-related stress-coping process. Journal of Individual Differences. https://doi.org/10.1027/1614-0001/a000033

Wey Smola, K., \& Sutton, C. D. (2002). Generational differences: Revisiting generational work values for the new millennium. Journal of Organizational Behavior: The International Journal of Industrial, Occupational and Organizational Psychology and Behavior, 23(4), 363-382. https://doi.org/10.1002/job.147

Wiley, M. G. (1991). Gender, work, and stress: The potential impact of role-identity salience and commitment. The Sociological Quarterly, 32(4), 495-510. https://doi.org/10.1111/j.15338525.1991.tb00150.x

Wynn, V. (1999). Selection and self: Selection as a social process. European Journal of Cognitive Psychology, 11(4), 385-402. https://doi.org/10.1080/713752329

Yunita, P. I., \& Saputra, I. G. N. W. H. (2019). Millennial generation in accepting mutations: Impact on work stress and employee performance. International Journal of Social Sciences and Humanities, 3(1), 102-114. 


\section{Biography of Authors}

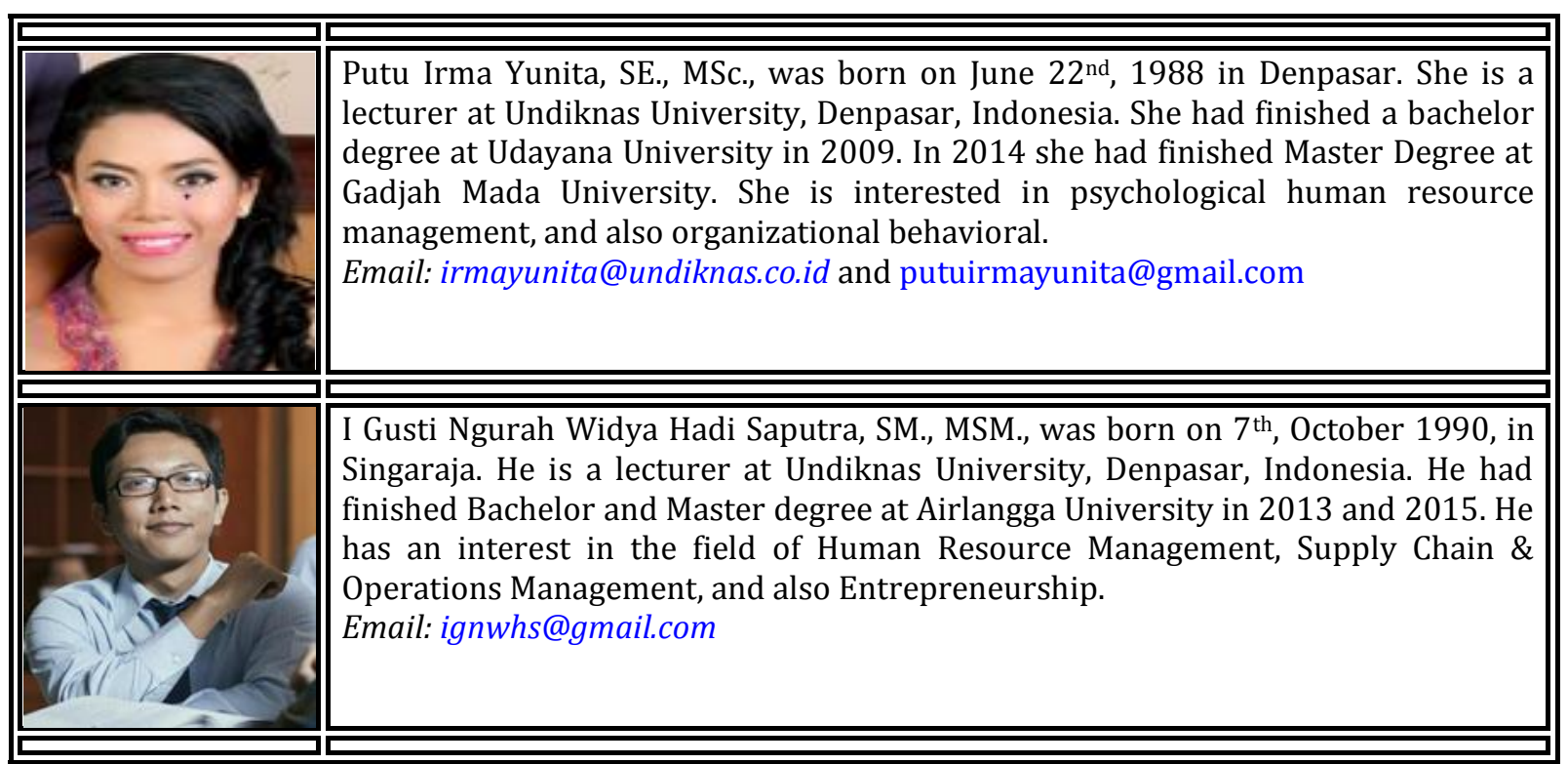

